\title{
Effects of Mg Partial Substitution for Pr on the Electrochemical Performances of Pr-Mg-Ni-based Alloys
}

\author{
Jianzhi Dou ${ }^{1, \dagger}$, Jingxuan Wei ${ }^{2, \dagger}$, Peng Wang ${ }^{3}$, Zhijie Gao ${ }^{4, *}$ \\ ${ }^{1}$ School of Applied Chemistry, Food and Pharmacy, Weifang Engineering Vocational College, \\ Qingzhou 262500, PR China \\ ${ }^{2}$ Binzhou Polytechnic, Binzhou, 256600, PR China \\ ${ }^{3}$ College of Airport, Binzhou University, Binzhou 256600, PR China \\ ${ }^{4}$ School of Automotive Engineering, Shandong Jiaotong University, Jinan 250023, PR China \\ $\dagger$ These authors contributed equally to this work \\ *E-mail: gaozhijie1983@126.com
}

doi: $10.20964 / 2019.06 .78$

Received: 16 March 2019 / Accepted: 23 April 2019 / Published: 10 May 2019

The influences of $\mathrm{Mg}$ substitution for $\mathrm{Pr}$ on the phase structures, hydrogen desorption characteristics and electrochemical properties of $\operatorname{Pr}_{1-\mathrm{x}} \mathrm{Mg}_{\mathrm{x}} \mathrm{Ni}_{3.1} \mathrm{Co}_{0.3} \mathrm{Al}_{0.1}(\mathrm{x}=0.0,0.1,0.15,0.17,0.2,0.25,0.3)$ alloys have been investigated. Partial replacement of $\mathrm{Mg}$ for Pr promotes the formation of super-stacking phases, refines crystal grains and decreases cell volumes. When $\mathrm{x} \leqslant 0.2$, the alloys consist of a main $\mathrm{Ce}_{2} \mathrm{Ni}_{7-}$ type $(\mathrm{Pr}, \mathrm{Mg})_{2} \mathrm{Ni}_{7}$ phase and a few $\mathrm{CaCu}_{5}$-type $\mathrm{PrNi}_{5}$ phase. As $\mathrm{Mg}$ content further increases, the alloys mainly contain $\mathrm{Ce}_{2} \mathrm{Ni}_{7}$-type $(\mathrm{Pr}, \mathrm{Mg})_{2} \mathrm{Ni}_{7}, \mathrm{PuNi}_{3}$-type $\mathrm{Pr}_{2} \mathrm{MgNi}_{9}$ and $\mathrm{CaCu}_{5}$-type $\mathrm{PrNi}_{5}$ phases. The plateau pressure of hydrogen desorption is initially increased and then decreased by the substitution and the reversibility is enhanced. Electrochemical analysis shows that the cycling stability for the alloy with $\mathrm{x}=0.15 \sim 0.17$ reaches $87.8 \%$ after 100 charge/discharge cycles. Meanwhile the maximum discharge capacity is improved. Further study shows that $\mathrm{Mg}$ increases the ratio of super-stacking structures so that the discharge capacity is enhanced. $\mathrm{Mg}$ optimize $\mathrm{P}_{\text {eq }}$ by adjusting the cell volumes of the phases so as to ameliorate the electrochemical performances. Alloys with $\mathrm{x}=0.15 \sim 0.17$ shows the optimal electrochemical performances.

Keywords: Pr-Mg-Ni-based hydrogen storage alloy, Mg substitution, Microstructure, Electrochemical properties

\section{$\underline{\text { FULL TEXT }}$}

(C) 2019 The Authors. Published by ESG (www.electrochemsci.org). This article is an open access article distributed under the terms and conditions of the Creative Commons Attribution license (http://creativecommons.org/licenses/by/4.0/). 